\title{
Hepatitis C virus: evidence for sexual transmission
}

\author{
R S Tedder, R J C Gilson, M Briggs, C Loveday, C H Cameron, J A Garson, G E Kelly, I V D Weller
}

Academic Departments of Urology and Genitourinary Medicine, University College and Middlesex School of Medicine, R S Tedder, MRCPATH, professor of medical virology R J C Gilson, MRCP, senior lecturer in genitourinary medicine

M Briggs, BSC, research associate in virology C Loveday, PHD, lecturer in virology

C H Cameron, FRCPATH, senior lecturer in virology

$\mathrm{J}$ A Garson, MD, senior lecturer in virology $\mathrm{G}$ E Kelly, PHD, lecturer in statistics

I V D Weller, FRCP, reader in genitourinary medicine

Dr Cameron died in

November 1990.

Correspondence and requests for reprints to Professor R S Tedder.

BMF 1991;302:1299-302 London WC1E 6JJ

\section{Abstract}

Objective-To determine the prevalence of hepatitis $\mathbf{C}$ virus infection and associated risk factors in patients attending a genitourinary medicine clinic, as evidence for sexual transmission.

Design-Seroprevalence estimated by reactivity in an enzyme immunoassay for antibodies to $\mathrm{C100}$ protein with supplementary testing with a recombinant immunoblot assay and an assay for hepatitis C virus RNA.

Setting-Outpatient genitourinary medicine clinic in central London.

Patients - The panel of 1046 serum samples was from 1074 consecutive patients attending the clinic during November and December 1987 and having blood taken for routine testing for syphilis. Before samples were anonymised demographic and risk factor information was extracted from the clinic notes. Samples had already been tested for antibody to HIV-I and antibody to hepatitis B core antigen.

Main results-Significantly more homosexual subjects than heterosexual subjects were positive for hepatitis $\mathbf{C}$ antibody determined by enzyme immunoassay alone $(19 / 275(6.9 \%) v 8 / 771(1.0 \%)$, odds ratio $7 \cdot 14, p<0.0001)$ and also when reactive serum samples were also tested by recombinant immunoblot assay $(6 / 270)(2.2 \%) v 3 / 770(0.4 \%)$, odds ratio $5 \cdot 88, p<0.02)$. There were also significant associations in patients positive for hepatitis $\mathrm{C}$ antibody with positivity for antibodies to HIV and to hepatitis $B$ core antigen, lifetime number of sexually transmitted diseases (homosexual men only), and age (all groups combined). Most patients whose serum samples contained specific antibodies to hepatitis $\mathrm{C}$ virus were viraemic.

Conclusions - The study provides strong evidence for the sexual transmission of hepatitis $C$ virus. Assays derived from other gene products are desirable to investigate the specificity and sensitivity of the enzyme immunoassay for $\mathrm{C100}$ antibody as a marker of hepatitis $\mathbf{C}$ virus infection.

\section{Introduction}

A number of bloodborne systemic viral infectionsfor example, human immunodeficiency virus (HIV), hepatitis B virus, and Ebola virus - may be transmitted between partners during sexual intercourse. There is epidemiological evidence that sexual contact is a

TABLE I - Demographic features and markers for hepatitis B virus and HIV in patients tested for serological evidence of hepatitis $C$ virus infection

\begin{tabular}{lccc}
\hline & $\begin{array}{c}\text { Homosexual or } \\
\text { bisexual men } \\
(\mathbf{n}=275)\end{array}$ & $\begin{array}{c}\text { Heterosexual men } \\
(\mathbf{n}=368)\end{array}$ & $\begin{array}{c}\text { Women } \\
(\mathbf{n}=403)\end{array}$ \\
\hline $\begin{array}{l}\text { Mean (range) age (years) } \\
\text { Mean (range) lifetime No of episodes of sexually } \\
\quad \text { transmitted disease }\end{array}$ & $33 \cdot 3(18-62)$ & $30 \cdot 3(18-82)$ & $27 \cdot 1(14-67)$ \\
No (\%) positive for antibody to hepatitis B core antigen & $\begin{array}{c}130 / 270(48) \\
\text { No(\%) positive for antibody to HIV }\end{array}$ & $\begin{array}{c}1 \cdot 1(0-11) \\
25 / 364(7)\end{array}$ & $\begin{array}{r}0 \cdot 6(0-12) \\
40 / 393(10)\end{array}$ \\
\hline
\end{tabular}

risk factor for acute non-A, non-B hepatitis, ${ }^{1}$ which suggests that the agent responsible may be sexually transmissible. The recent cloning and expression of an RNA viral genome from the plasma of chimpanzees infected with human non- $A$, non-B hepatitis virus has made possible the partial characterisation of a virus, now termed hepatitis $\mathrm{C}$ virus, and the development of an assay for antibody to hepatitis $\mathrm{C}$ virus, ${ }^{23}$ which is able to identify most infected individuals. In this assay the target antigen is the non-structural hepatitis $C$ virus protein $\mathrm{Cl} 0$ as expressed in Saccharomyces cerevisiae as the major part of a superoxide dismutase fusion protein, C100-3.

The prevalence of infection as judged by the detection of antibody to C100 with this assay is low in the United Kingdom. ${ }^{4}$ Initial observations of a raised prevalence in homosexual men $^{56}$ and in a small number of heterosexuals with multiple partners (M J Alter, personal communication) are difficult to interpret in the absence of any means of confirming the specificity of the reactivity in the test used. A recent retrospective longitudinal study among 259 homosexual patients indicated that seroconversion for $\mathrm{C} 100$ antibody was rare and suggested that the acquisition or presence of this antibody was unrelated to sexual lifestyles. ${ }^{7}$ We report here an investigation into the prevalence of this reactivity to $\mathrm{C} 100$ antigen in 1046 patients attending a genitourinary medicine clinic. Supplementary testing with a recombinant immunoblot assay and an assay for the hepatitis $C$ virus genome was used in the analysis of those serum samples found to be reactive. The results indicated that hepatitis $\mathrm{C}$ virus is likely to be sexually transmitted.

\section{Materials and methods}

Serum samples, stored at $-20^{\circ} \mathrm{C}$ and not inactivated by heat, were from consecutive patients bled for routine syphilis testing when attending a genitourinary medicine clinic in November and December 1987. Before samples were anonymised, characteristics as recorded routinely in patients' notes were extracted. They included age, sexual orientation, and lifetime number of episodes of sexually transmitted diseases (counting only one episode of genital warts and herpes simplex). Serum samples were obtained from 1074 patients, but sufficient serum remained from 1046 patients for this study (table I). The distribution of sexual orientation and age of patients tested was similar to those not tested. Any recorded history of injecting drug use was noted, but this was not routinely sought. Antibodies to hepatitis B virus core antigen and to HIV were detected as previously described. ${ }^{8}$

Antibody to hepatitis $\mathrm{C}$ virus was detected with a commercial enzyme immunoassay (Ortho Diagnsotic Systems) according to the manufacturer's instructions. The assay is of the widely used antiglobulin format, using the $\mathrm{C100-3}$ fusion protein on the solid phase and an enzyme conjugated antihuman IgG to detect bound antibody. The calculated cut off value is derived by 
adding a constant $(0 \cdot 4)$ to the mean optical density of the negative controls.

In this study, the samples found to be negative were further subdivided into two groups, non-reactive (less than 0.2 above the mean negative control optical density) and reactive (from 0.2 to less than 0.4 above the mean negative control optical density). Those samples found to be positive were subdivided into weak positive and strong positive, relative to the midvalue between the calculated cut off and the kit positive control.

Samples repeatedly found to be above the calculated cut off in the enzyme immunoassay for $\mathrm{C} 100$ antibody were further examined in a recombinant immunoblot assay (Ortho Diagnostic Systems). The recombinant immunoblot assay is a strip enzyme immunoassay used like a western blot, presenting recombinant hepatitis $C$ virus antigens in two separate bands, the original 5-1-1 clone expressed in Escherichia coli (representing only a portion of the $\mathrm{C} 100$ antigen), and the C100-3 fusion protein, which is derived from the overlapping clones 5-1-1, 81, 36, and 32 and expressed by fusion to the human superoxide dismutase gene in $S$ cerevisiae. Superoxide dismutase protein, together with high and low immunoglobulin control bands, is also included. For a serum reaction to be deemed specific, bound antibodies must be detected on both the 5-1-1 and the C100-3 bands. Samples that were positive in the enzyme immunoassay were also analysed for hepatitis C virus RNA by reverse transcription and a nested polymerase chain reaction for hepatitis $\mathrm{C}$ virus complementary DNA initially using primers in coding regions. ${ }^{+}$Where available, samples were also analysed using primers in the highly conserved non-coding sequences as previously described. ${ }^{9}$

Odds ratios with $95 \%$ confidence intervals were

TABLE II - Interrelationship of risk factors included in analysis with hepatitis $C$ virus infection

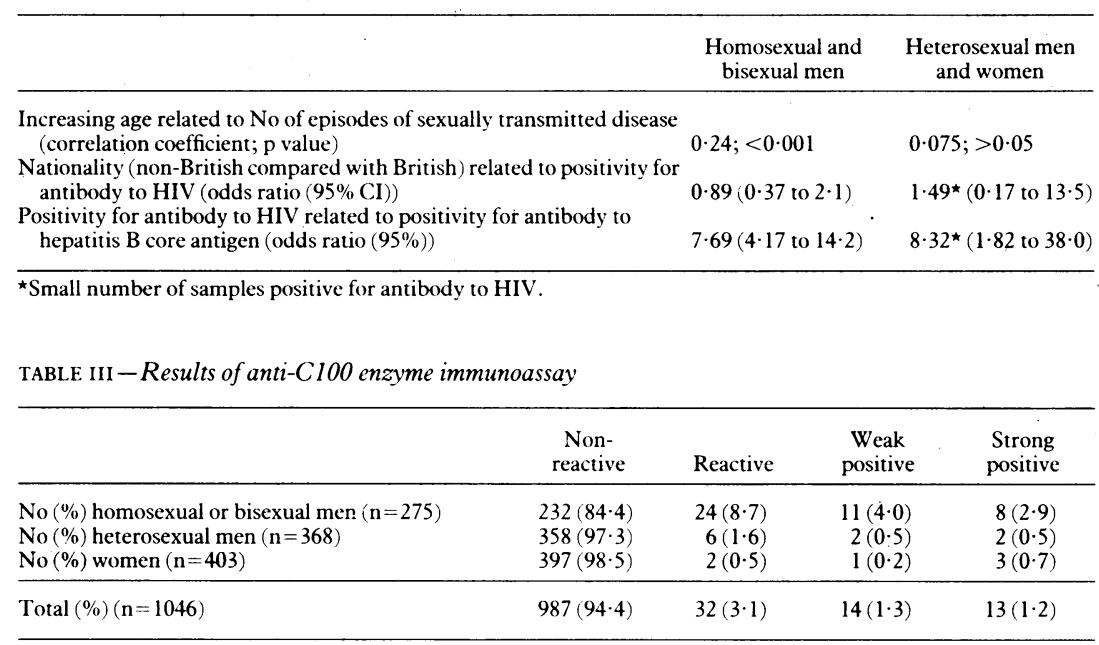

calculated in a univariate analysis of risk factors using Statistical Analysis System software. Where sexual orientation was analysed as a risk factor homosexual men and bisexual men were considered together. For continuous variables (age and lifetime number of sexually transmitted diseases) the maximum likelihood estimate, the exponential of the regression coefficient in a logistic regression model, was calculated. The odds ratio increases by a factor of the maximum likelihood estimate for each unit increase (one year of age or one episode of sexually transmitted disease) in the continuous variable. The numbers in the risk groups were insufficient to allow a multivariate analysis of risk factors, but significant associations were found between some of the risk factors (table II).

\section{Results}

Table III shows the results of the enzyme immunoassay for $\mathrm{C} 100$ antibody. Positive results, interpreted according to the manufacturer's instructions, were obtained in 27 of 1046 (2.6\%) samples, including 19 of $275(6.9 \%, 95 \%$ confidence interval 3.9 to 9.9$)$ from homosexual or bisexual men and eight of $763(1 \cdot 0 \%, 0 \cdot 3$ to $1 \cdot 8$ ) from heterosexual men and women. Positivity in this immunoassay was strongly associated with male homosexuality (odds ratio $7 \cdot 14,3.03$ to $16 \cdot 7, \mathrm{p}<0.0001$ compared with heterosexual men and women combined). In a univariate analysis of risk factors (table IV) positivity in this immunoassay among homosexual men was associated with positivity for antibody to hepatitis B core antigen and for antibody to HIV and with increasing lifetime number of sexually transmitted diseases. Among heterosexual men and women there were significant associations with positivity for antibody to hepatitis B core antigen and HIV. Increasing age was associated with positivity in the immunoassay for $\mathrm{Cl00}$ antibody for all patients combined (maximum likelihood estimate $1.05,1.02$ to $1.09, \mathrm{p}<0.002$ but, although the trend remained, the association did not reach significance when groups were analysed separately. There was an association with North American, Australian, or European nationality but not with other nationalities among homosexual men. There was no association with the presence or absence of a sexually transmitted disease diagnosed at that clinic visit.

Of the serum samples in the reactive category (table III), a higher proportion were from homosexual men (24/32) and were positive for antibody to HIV (21/32) and antibody to hepatitis B core antigen (19/32) than was found in the non-reactive category (232/987, $54 / 987,164 / 976$ respectively; $\mathrm{p}<0.0001$ for each comparison by $\chi^{2}$ test). These serum samples were not analysed further.

To confirm the $\mathrm{C} 100$ specificity of the reactions detected, 21 of the 27 samples positive on enzyme

TABLE IV-Univariate analysis of risk factors for positivity for antibody to C100

\begin{tabular}{|c|c|c|c|c|c|c|c|c|c|c|c|c|}
\hline \multirow[b]{3}{*}{ Risk factor } & \multicolumn{6}{|c|}{ Positivity interpreted according to manufacturer's instructions } & \multicolumn{6}{|c|}{ Positivity confirmed by supplementary testing ${ }^{\star}$} \\
\hline & \multicolumn{3}{|c|}{ Homosexual men } & \multicolumn{3}{|c|}{ Heterosexual men and women } & \multicolumn{3}{|c|}{ Homosexual men } & \multicolumn{3}{|c|}{ Heterosexual men and women } \\
\hline & Odds ratio & $95 \% \mathrm{CI}$ & p Value & Odds ratio & $95 \% \mathrm{CI}$ & $\mathrm{p}$ Value & Odds ratio & $95 \% \mathrm{CI}$ & $\mathrm{p}$ Value & Odds ratio & $95 \% \mathrm{CI}$ & $\mathrm{p}$ Value \\
\hline $\begin{array}{l}\text { Increasing age } \\
\text { Nationality }\end{array}$ & $1 \cdot 03+$ & 0.99 to 1.08 & NS & $1 \cdot 04 \dagger$ & $0 \cdot 90$ to $1 \cdot 11$ & NS & $1.06 \dagger$ & 0.98 to $1 \cdot 10$ & NS & $1.03 t$ & 0.94 to $1 \cdot 15$ & NS \\
\hline Group $1 \neq v$ British & $\begin{array}{l}3 \cdot 51 \\
1 \cdot 30\end{array}$ & $\begin{array}{l}1 \cdot 15 \text { to } 10 \cdot 7 \\
0.16 \text { to } 10 \cdot 7\end{array}$ & $\begin{array}{c}<0.03 \\
\text { NS }\end{array}$ & $\begin{array}{l}1 \cdot 90 \\
0\end{array}$ & 0.38 to $9 \cdot 52$ & NS & $\begin{array}{l}5 \cdot 0 \\
0\end{array}$ & $1 \cdot 3$ to $19 \cdot 0$ & $<0.02$ & $\begin{array}{l}2 \cdot 86 \\
0\end{array}$ & 0.26 to 31.9 & NS \\
\hline Hepatitis B virus infection $\$$ & 5.96 & 1.68 to $21 \cdot 1$ & $<0.006$ & $8 \cdot 32$ & 1.82 to 38.0 & $<0.006$ & $5 \cdot 6$ & 0.65 to 48.7 & NS & $\infty$ & & \\
\hline HIV infection $₫$ & $23 \cdot 0$ & $5 \cdot 19$ to 102 & $<0.0001$ & $18 \cdot 0$ & 1.91 to 170 & $<0.012$ & $12 \cdot 1$ & 1.4 to 106 & $<0.03$ & $63 \cdot 4$ & $5 \cdot 0$ to 797 & $<0 \cdot 002$ \\
\hline $\begin{array}{l}\text { Increasing lifetime number of } \\
\text { sexually transmitted diseases }\end{array}$ & $1 \cdot 18 \dagger$ & 1.07 to 1.31 & $<0.001$ & $0.69+$ & $0 \cdot 28$ to $1 \cdot 7$ & NS & $1 \cdot 12 \dagger$ & $1 \cdot 02$ to $1 \cdot 24$ & $<0.03$ & $0 \cdot 64 \dagger$ & $0 \cdot 13$ to $3 \cdot 17$ & NS \\
\hline
\end{tabular}

NS= Not significant.

NS = Not significant.
^Assuming all serum samples unreactive are negative and only those positive by enzyme immunoassay are positive (samples positive by anti-C100 enzyme immunoassay but not tested by recombinant immunoblot assay are considered as missing values).

† Maximum likelihood estimate in a logistic regression model.

fGroup I = Europe, North America, Australasia; group 2=Africa, Indian subcontinent, Middle and Far East, Caribbean, Central and South America.

\Positivity for antibody $v$ negativity for antibody. 
TABLE $\mathrm{v}-$ Results of supplementary testing of serum samples positive by anti-C100 enzyme immunoassay

\begin{tabular}{|c|c|c|c|c|c|c|}
\hline \multicolumn{3}{|c|}{ Recombinant immunoblot assay } & \multicolumn{4}{|c|}{ Nested polymerase chain reaction for viraemia } \\
\hline \multirow[b]{2}{*}{ Negative } & \multirow[b]{2}{*}{ Positive } & \multirow[b]{2}{*}{ Not tested } & \multicolumn{2}{|c|}{ Coding primers } & \multicolumn{2}{|c|}{ Non-coding primers ${ }^{\star}$} \\
\hline & & & Negative & Positive & Negative & Positive \\
\hline
\end{tabular}

\begin{tabular}{lccccccc}
\hline Positive $(\mathrm{n}=14)$ & 10 & 1 & 3 & 14 & NT & NT \\
Strongly positive $(\mathrm{n}=13)$ & 2 & 8 & 3 & 12 & 1 & 3 & 5 \\
\hline
\end{tabular}

NT $=$ Not tested.

$\star$ Only eight samples available

for testing. immunoassay (those with sufficient serum remaining) were tested by the recombinant immunoblot assay. Nine samples (six from homosexual men) gave positive reactions by the recombinant immunoblot assay (table $\mathrm{V}$ ), giving a prevalence of $2 \cdot 2 \%(0 \cdot 5$ to $4 \cdot 0)$ in the 275 samples from homosexual or bisexual men and $0.4 \%(0$ to 0.8$)$ in 763 samples from heterosexual subjects. There was again a significant association with male homosexuality (odds ratio $5 \cdot 88,1.45$ to $25 \cdot 0$, $\mathrm{p}<0.02$ )

The further univariate analysis (table IV) showed that positivity for antibody to HIV was associated with reactivity for antibody to $\mathrm{C} 100$ antigen in both homosexual and heterosexual subjects. Positivity for antibody to hepatitis B core antigen was now only associated when the groups were combined (odds ratio $36 \cdot 0,4 \cdot 5$ to $290, \mathrm{p}<0 \cdot 001$ ). Age was still significantly associated only in the combined groups (maximum likelihood estimate $1 \cdot 06,1 \cdot 01$ to $1 \cdot 12, \mathrm{p}<0 \cdot 03$ ). Lifetime number of sexually transmitted diseases remained significantly associated in homosexual men. The analysis of the interrelationship of risk factors (table II) suggests that similar findings would have been produced if a multivariate analysis could have been performed, but because of the strong association between positivity for antibodies to HIV and hepatitis $B$ virus core antigen, both of these factors would probably not be significant simultaneously.

All 27 serum samples positive by the immunoassay for $\mathrm{C} 100$ antibody were tested for hepatitis $\mathrm{C}$ virus RNA (table V). With coding primers, only one sample, from a woman with a history of injecting drug use (a sample strongly positive by enzyme immunoassay and positive by recombinant immunoblot assay), contained detectable hepatitis $C$ virus RNA. When eight samples that were reactive in the recombinant immunoblot assay were retested using $5^{\prime}$ non-coding region primers five samples (including the one from the woman previously found to be positive for hepatitis C RNA), were found to contain detectable virus specific RNA.

\section{Discussion}

We examined the prevalence of reactivity to the $\mathrm{C} 100$ protein in an enzyme immunoassay in a well characterised panel of serum samples collected, as previously described, ${ }^{8}$ from 1074 consecutive patients attending a genitourinary medicine clinic. This was undertaken to examine the possibility of sexual transmission of hepatitis $\mathrm{C}$ virus. Previous studies that used the same immunoassay for $\mathrm{C} 100$ antibody but did not use supplementary testing have provided conflicting results. In a small study of a group of 26 homosexual men in Spain ( $96 \%$ HIV positive), serum samples from two $(8 \%)$ were positive in the $\mathrm{Cl} 100$ enzyme immunoassay. ${ }^{5}$ In an uncontrolled cohort study of 259 homosexual men in Denmark Melbye et al found a cumulative incidence of reactivity in the immunoassay of $4 \cdot 1 \%$ in 1989 , but they failed to show any significant association with risk factors for sexually transmitted diseases. ${ }^{7}$ In the United Kingdom, samples from 14 of 95 (15\%) homosexual men were positive on enzyme immunoassay, and there was a significant association with positivity for antibody to HIV ( $26 \%$ of HIV positive men $v 4 \%$ of HIV negative men). ${ }^{6}$ In the United States a significant association between numbers of recent sexual partners and positivity on enzyme immunoassay was shown among the heterosexual control group in a study of acute non-A, non-B hepatitis. Three of 19 people $(16 \%)$ with more than two partners in the preceding six months were positive on enzyme immunoassay compared with eight of 281 (3\%) with two or fewer partners ( $M$ J Alter, personal communication). In another study from Spain, however, positivity on enzyme immunoassay was found in only one serum sample from 21 female partners of injecting drug users who were known to be positive for antibody to $\mathrm{C} 100$, and in none of the 40 spouses of other patients who had been found to be positive ( $R$ Esteban, personal communication). None of these studies have used supplementary assays to validate their results. In our study the prevalence of positivity on the immunoassay alone and with supplementary testing in homosexual and bisexual men was significantly higher than in heterosexual subjects. In all groups the presence of antibody was associated with previous exposure to HIV and hepatitis B virus infection, and in homosexual men with the lifetime number of sexually transmitted diseases. Though these findings are entirely compatible with sexual transmission, some caution is required because the data on sexual orientation and lifetime number of sexually transmitted diseases were obtained retrospectively from clinic records. In our experience, in a genitourinary medicine clinic sexual orientation is usually correctly reported but the number of episodes of sexually transmitted disease may be underestimated.

The group of samples for which the immunoassay result fell within the reactive band (but below the manufacturer's cut off) contained an excess of those from homosexual or bisexual men and an excess of samples positive for antibodies to HIV and hepatitis B core antigen. This observation may imply that the cut off value used does not encompass the weaker true positive reactions, but it has not been investigated further. It has been suggested that heat inactivated or frozen stored serum may give false positive reactions in this enzyme immunoassay for $\mathrm{C} 100$ antibody. ${ }^{6}$ Serum from patients with chronic liver disease also may give false positive reactions in antiglobulin assays proportional to their raised serum immunoglobulin levels. ${ }^{10}$ In view of these potential problems, which are common to other antiglobulin assays, those samples positive in the immunoassay for $\mathrm{Cl} 100$ antibody were also examined in a supplementary assay, the recombinant immunoblot test, which is itself an antiglobulin assay. Among samples that were repeatedly positive, those with stronger reactions in the enzyme immunoassay were more likely to give concordant results by the recombinant immunoblot assay. The recombinant immunoblot assay is based in part on the same recombinant antigen $(\mathrm{Cl} 100-3)$ used in the enzyme immunoassay, limiting its value as a confirmatory test of hepatitis $\mathrm{C}$ virus infection. Though the strategy confirms the presence of specific antibody to the $\mathrm{C} 100$ gene product, it does not confirm that the response to $\mathrm{C} 100$ protein is due to prior or current hepatitis $\mathrm{C}$ virus infection. This can be confirmed serologically only by showing antibodies to the products of one or more hepatitis $\mathrm{C}$ virus genes other than $\mathrm{C} 100$

When the analysis of results was restricted only to positivity for antibody to $\mathrm{Cl} 00$ confirmed by recombinant immunoblot assay, the prevalence was still significantly higher in homosexual or bisexual men than in heterosexuals. The association of positivity for antibody to $\mathrm{Cl} 100$ with increasing age, number of sexually transmitted diseases, and positivity for antibody to HIV remained. This provides strong evidence for sexual transmission of hepatitis $C$ virus, although 
the numbers in individual groups were too small to allow a multivariate analysis. Unfortunately, six serum samples that were repeatedly positive in the enzyme immunoassay could not be tested by the recombinant immunoblot assay. However, even on the most cautious assumption - that the sample from the one heterosexual subject would have been confirmable by the recombinant immunoblot assay, and that the samples from the five homosexual subjects would not have been confirmable-the association of homosexuality with confirmed positivity for $\mathrm{C} 100$ antibody would remain significant $(p<0 \cdot 05)$.

If the antibody reactivity represents a specific antibody response to prior infection with hepatitis $C$ virus then it seems that most patients whose serum samples contained $\mathrm{C} 100$ antibody and were available for testing with the 5 ' non-coding region primers contained virus. The detection of virus in most serum samples from the homosexual men studied in which antibody was detected may imply that hepatitis $\mathrm{C}$ virus is maintained within this group largely by transmissions from chronically infected people. The failure in some cases of the primers based on coding regions to detect this virus is further confirmation of the genetic variability of the virus. It is important that further studies of patterns of viraemia should take this into account when sequence targets for amplification are being chosen. With the use of the non-coding primers, the prevalence of viraemia in our patients compares with that observed in haemophiliac patients: those whose serum contains $\mathrm{C} 100$ antibody are commonly viraemic (unpublished data). There are few data at present to indicate different outcomes of hepatitis $C$ virus infection depending upon the viral dose or route of transmission, or both.

We have shown an unequivocal association between C100 antibody and male homosexuality in patients attending a genitourinary medicine clinic. The biology of hepatitis $\mathrm{C}$ virus infection in this group of patients does not differ from that seen in post-transfusion hepatitis and in haemophiliac patients. Although detection of hepatitis $C$ virus RNA by the polymerase chain reaction is an invaluable test for identifying the patient who remains a carrier, an assay for detecting circulating viral antigens would be a useful adjunct and be more suitable for screening and large scale studies. Assays for detecting antibodies to proteins other than $\mathrm{Cl} 100$ are also desirable for elucidating more completely the clinical course and epidemiology of hepatitis C virus infection.

RJCG was supported by the clinical research and development committee of University College and Middlesex School of Medicine. We thank colleagues at Wellcome Diagnostics and the North London Blood Transfusion Centre for helpful discussions; Sarah Jacob and Phil Tuke for technical assistance; and Peter Williams for statistical assistance.

1 Alter MJ, Coleman PJ, Alexander WJ, et al. Importance of heterosexual activity in the transmission of hepatitis $B$ and non-A, non-B hepatitis. fAMA 1989;262:1201-5.

2 Choo QL, Kuo G, Weiner AJ, Overby LR, Bradley DW, Houghton $M$. Isolation of a cDNA clone derived from a blood borne non-A, non-B viral hepatitis genome. Science 1989;244:359-62.

3 Kuo G, Choo QL, Alter HJ, et al. An assay for circulating antibodies to a major etiologic virus of human non-A, non-B hepatitis. Science 1989;244:362-4.

4 Garson JA, Tedder RS, Briggs $M$, et al. Detection of hepatitis C viral sequences in blood donations by "nested" polymerase chain reaction and sequences in blood donations by "nested" polym

5 Esteban JI, Esteban R, Viladomiu L, et al. Hepatitis $C$ virus antibodies among risk groups in Spain. Lancet 1989;ii:294-7.

risk groups in Spain. Lancet 1989;ii:294-7.
Mortimer PP, Cohen BJ, Litton PA, et al. Hepatitis C virus antibody. Lancet Mortimer PP, Cohe
1989;ii:798.

7 Melbye M, Biggar RJ, Wantzin P, Krogsgaard K, Ebbesen P, Becker NG Sexual transmission of hepatitis $C$ virus: cohort study (1981-9) amon European homosexual men. BMF 1990;301:210-2.

8 Loveday C, Pomeroy L, Weller IVD, et al. Human immunodeficiency viruses in patients attending a sexually transmitted disease clinic in London, 1982-7. BMf 1989;298:419-22.

9 Garson JA, Ring C, Tuke P, Tedder RS. Enhanced detection by PCR of hepatits C virus RNA. Lancet 1990;336:878-9.

10 McFarlane IG, Smith HM, Johnson PJ, Bray GP, Vergani D, Williams R. Hepatitis $C$ virus antibodies in chronic active hepatitis: pathogenetic factor or false positive result? Lancet 1990;335:754-7.

(Accepted 10 April 1991)

\title{
Association between infection with Helicobacter pylori and risk of gastric cancer: evidence from a prospective investigation
}

\author{
D Forman, D G Newell, F Fullerton, J W G Yarnell, A R Stacey, N Wald, F Sitas
}

\begin{abstract}
Objective-To investigate the association between gastric cancer and prior infection with Helicobacter pylori.

Design-Case-control comparison of prevalence of IgG antibodies to $H$ pylori in blood samples collected prospectively, before diagnosis of gastric cancer in the cases. Presence of $\boldsymbol{H}$ pylori antibody $(>10 \mu \mathrm{g} \mathrm{IgG} / \mathrm{ml})$ determined by enzyme linked immunosorbent assay (ELISA).

Subjects -29 men with a subsequent diagnosis of gastric cancer and 116 aged matched controls selected from over 22000 middle aged men participating in two ongoing cohort studies (the British United Provident Association study and the Caerphilly collaborative heart disease study), who had provided blood samples during 1975-1982.

Results -20 of the 29 cases $(69 \%)$ and 54 of the 116 controls $(47 \%)$ were positive for $H$ pylori specific antibody. The median specific IgG concentration was significantly higher in the cases than controls $(90 \mu \mathrm{g} / \mathrm{ml} v 3.6 \mu \mathrm{g} / \mathrm{ml}, \mathrm{p}<0.01)$. The estimated odds ratio for the risk of gastric cancer in those with a history of infection with $\boldsymbol{H}$ pylori was $2.77(95 \%$ confidence interval 1.04 to $7.97,2 p=0.039$ ).
\end{abstract}

Conclusions-H pylori infection may be an important cause of gastric cancer; between $35 \%$ and $55 \%$ of all cases may be associated with such an infection.

\section{Introduction}

The bacterium Helicobacter pylori is a causative agent in the development of chronic antral gastritis. ${ }^{1}$ Because gastritis, when it becomes atrophic, is a condition that predisposes to precancerous changes in the stomach ${ }^{2} H$ pylori infection is also proposed to be involved in the development of gastric cancer. ${ }^{3}$ The high prevalence of $H$ pylori infection at an early age in population groups at high risk of gastric cancer ${ }^{4-6}$ supports such a hypothesis. In a recent geographical correlation study in China mortality from gastric cancer showed a significant correlation of $40 \%$ with the prevalence of antibody to $H$ pylori. ${ }^{7}$ Clinical studies based on histopathological examination of gastric biopsy specimens showed that $H$ pylori infection is more common in patients with gastric cancer than patients with no pathological lesions..$^{8-10}$

We report findings of two prospective studies in which over 22000 middle aged men in England and
Correspondence to: $\mathrm{Dr}$ BMf 1991;302:1302-5 